\title{
SUSTAINABLE MOUNTAIN
}

AGRICULTURE

perspectives and issues

\section{VOLUME 1}

Editors

N.S. JODHA

M. BANSKOTA 
Mountain agriculture, the dominant sector of mountain economies in the developing countries has suffered a serious decline or stagnation in the recent decades. In most parts of the mountains, the emerging scenarios indicate a widening gap between demand and supply of land resources and land-based products on the one hand and unsustainability of current resource use patterns and production activities on the other. These factors constitute the background to the studies reported in the present book. The focus of the text is on the understanding and identification of factors and processes contributing to the sustainability or unsustainability of mountain agriculture and related activities. Most of the involved issues are identified and analysed with reference to 'Mountain Perspective-Sustainability Framework' evolved by ICIMOD to examine the relevance of interventions to specific conditions of mountains.

The present book, in two volumes, synthesizes results of ICIMOD studies in the selected hill areas of India, China, Nepal and Pakistan, which were presented at an International Sym. posium on Strategies for Sustainable Agriculture in Mountain Regions. The themes covered are public policies and programmes, farmers' resource management strategies, some successful development initiatives, long-term issues in sustainability and zonation as a tool for designing development strategies for diverse mountain areas. Contributions from Andes mountain agriculture enrich the text which otherwise, is confined to the Hindu Kush Himalayan Region. This is an effort to identify approaches and options for sustainable development of mountain areas and mountain agriculture. The important message is to learn from the past and have a fresh look at the conventional development approaches to mountain areas. 


\title{
SUSTAINABLE MOUNTAIN AGRICULTURE \\ Perspectives and Issues
}

\author{
VOLUME 1
}

Editors

N.S. JODHA, M. BANSKOTA and TEJ PARTAP

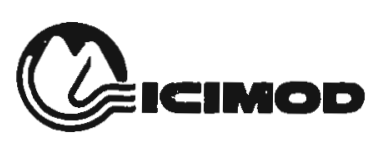

International Centre for Integrated

Mountain Development, Kathmandu

OXFORD \& IBH PUBLISHING CO. PVT. LTD. 
(C) 1992 International Centre for Integrated Mountain Development, Kathmandu

Set ISBN 81-204-0620-6

Vol. 1 ISBN 81-204-0621-4

Vol. 2 ISBN 81-204-0622-2

Published by Mohan Primlani for Oxford \& IBH Publishing Co. Pvt. Ltd., 66 Janpath, New Delhi 110001 . Phototypeset by Laserwords, Madras, processed and printed at Pauls Press, E44/11 Okhla Industrial Area, Phase II, New Delhi 110020. 


\section{CONTENTS}

\section{VOLUME 1}

Foreword

vii

Preface

ix

Editors' Note

Acknowledgements

$\mathrm{xi}$

The Contributors

xii

xiii

PART 1: AGRICULTURE DEVELOPMENT IN MOUNTAIN AREAS:

PERSPECTIVES AND APPROACHES

Chapter 1. Strategies for the Sustainable Development of Mountain

Agriculture: An Overview

N.S. Jodha, M. Banskota and T. Partap

Chapter 2. Mountain Perspective and Sustainability: A Framework

for Development Strategies

N.S. Jodha

Chapter 3. Mountain Agricultural Development Strategies:

Comparative Perspectives from the Countries of the

Hindu Kush-Himalayan Region

M. Banskota and N.S. Jodha

Chapter 4. Mountain Agricultural Development Strategies: The Andean

Perspective

M.E. Tapia

Chapter

5. Mountain Farmers' Response to Development Efforts:

Comparative Perspectives from the Countries of the

Hindu Kush-Himalayan Region

S. Sharma and N.S. Jodha

Chapter

6. Farming-Forestry-Livestock-Linkages: A Component of

Mountain Farmers' Strategies (Nepal)

Y. Yadav 
PART 2: $\quad$ LONG-TERM SUSTAINABILITY OF MOUNTAIN AGRICULTURE: SOME BASIC ISSUES

Chapter 7. Population Dynamics and Sustainable Agricultural

Development in Mountain Areas

$P$. Sharma and $M$. Banskota

Chapter 8. Investment, Subsidies, and Resource Transfer Dynamics:

Issues for Sustainable Mountain Agriculture

M. Banskota and N.S. Jodha

Chapter

9. Institutional Imperatives for Sustainable Resource

Management in the Mountains

D. Bajracharya

Chapter 10. Infrastructural Development Imperatives for Sustainable

Mountain Agriculture

B.B. Bajracharya

Chapter 11. Thinking Globally, Acting Locally: Technology

for Sustainable Mountain Agriculture

R.E. Rhoades

Chapter 12. Biological Diversity as an Issue in Sustainable

Development of Mountain Agriculture

T. Partap

PART 3: $\quad$ AGRO-ECOLOGICAL ZONATION APPROACHES TO MOUNTAIN DEVELOPMENT

Chapter 13. An Agro-ecological Zonation Approach to Agricultural

Planning in Mountain Environments

B. Carson

Chapter 14. Comparative Methods for Characterizing Mountain

Agro-ecosystems

P.A. Lundberg

Chapter 15. Geographic Information Systems (GIS) Technology

Application in Agro-ecological Zonation of Mountain

Environments

T. Partap, P. Pradhan, P.K. Kotta, S. Mya, Z. Karim and

G. Nakarmi

\section{VOLUME 2}

PART 4: $\quad$ MOUNTAIN FARMERS' STRATEGIES AND SUSTAINABILITY IMPLICATIONS

Chapter 16. Farmers' Innovations and Agricultural Technologies 
Chapter 17. Land-use Modification and Labour Shortage Impacts on the Loss of Native Crop Diversity in the Andean Highlands

K. Zirimerer

Chapter 18. Farmers' Strategies in the Mountain Areas of West Sichuan: China Liu Yanhua, Wang Fei and Yu Dafu

Chapter 19. Farmers' Strategies in the Middle Hills of Nepal

S. Shrestha and B. Katwal

Chapter 20. Diversity of Farming Systems and Farmers' Strategies in the Mountain Valley of Chitral, Pakistan Masood ul Mulk

Chapter 21. Diversity of Mountain Farming Systems in Himachal Pradesh, India I.P. Bhati, R. Singh, M.S. Rathore and L.R. Sharma

Chapter 22. Andean Farming Systems: Farmers' Strategies and Responses
A. Camino

Chapter

23. Indigenous Farming Technologies and Environment:

Experiences in Bhutan

A.K. Gupta and K. Ura

Chapter

24. Farmer-Managed Irrigation Systems in the Mountains of

Pakistan

E.J. Vander Velde

PART 5: $\quad$ TRANSFORMATION OF MOUNTAIN AREAS: SOME INNOVATIVE APPROACHES

Chapter 25. Anti-poverty Focussed Programmes in the Mountains:

Experiences in China

Gao Hongbin and Ye Xingquing

Chapter 26. The Experiences of an Area-based Development Strategy in Himachal Pradesh, India

L.R. Verma and T. Partap

Chapter 27. A Local Resource-Centred Approach to Rural Transformation: Agro-based Cottage Industries in Western Sichuan, China

Liu Zhaoguang and Wu Ning

Chapter 28. The Small Farmers' Development Programme in Nepal:

Institutional Initiative in Poverty Alleviation

K.S. Sharma

Chapter 29. The Aga Khan Rural Support Programme: An Approach to

Village Management Systems in Northern Pakistan

T. Husain

Chapter 30. Mountain Agricultural Technology Development and Diffusion:

The Lumle Model, NEPAL

B. Pound, K. Budathoki and B.R. Joshi 
vi Contents

Chapter 31. Mountain Agricultural Technology Development and Diffusion:

The Pakhribas Model, Nepal

S.P. Chand and B. Thapa

Chapter 32. Agricultural Research Experiences of the Arid Zone Research Institute (AZRI) in Baluchistan, Pakistan J.D.H. Keatinge and B. Roider Khan

Chapter 33. Agroforestry as an Option for Mountain Agricultural

Development

J. Denholm and N.S. Jodha 


\section{FOREWORD}

This document has been produced as part of the work programme of the Mountain Farming Systems Division of ICIMOD. Mountain Farming Systems is one of ICIMOD's four thematic research programmes.

The programme has now completed the first phase of work on Strategies for Sustainable Mountain Agriculture. To complete this phase, problem-oriented research work, in selected areas of the Hindu Kush-Himalayan Region, was conducted. The areas of the Region focussed upon were West Sichuan (China), Himachal Pradesh (India), the North West Frontier Province (NWFP) (Pakistan), and the Middle Hills of Nepal. The work involved thematic reviews of selected development policies and programmes, site-specific studies covering crop, livestock, and horticulture-dominated farming systems as well as other reviews covering specific topics such as underexploited plant genetic resources, mountain beekeeping, and innovative and successful initiatives in the field of agricultural technology and rural institutions.

Work was conducted in collaboration with national institutions and experts from the regional countries. During the course of the studies, different national workshops were held (in China, India, Nepal, and Pakistan) to discuss the findings in the countries where research was being conducted. The experience gained from these national workshops became the input for the International Symposium for Strategies on Sustainable Mountain Agriculture, held at Kathmandu from September 10-14, 1990.

In addition to papers based on the HKH Region, papers were presented on the Andean Region. This volume includes these papers as well as a number of papers selected from background material, produced through the auspices of ICIMOD, in order to give the reader a broader picture of the problems and concerns of Sustainable Mountain Agriculture.

In publishing this volume, ICIMOD is fulfilling a part of its mandate to facilitate the economically and environmentally sustainable development of mountain areas through the dissemination of relevant information. Since agriculture remains the principal occupation of the majority of the inhabitants of the Hindu Kush-Himalaya, it is understood that Mountain Farming Systems merit a great deal of study, especially within the context of long-term sustainability. ICIMOD hopes that this volume will serve to add to the understanding of these systems and to the long-term benefit of mountain peoples.

Several organisations have supported ICIMOD's endeavours in this particular study, and I would like to acknowledge the support of the Asian Development Bank (ADB) and the Ford Foundation in helping us to undertake this work. In addition, the UNDP, the Rockefeller Foundation, and the Swiss Development Cooperation facilitated the par- 
ticipation of various experts in the workshops held. His Majesty's Government of Nepal and a number of other organisations in Nepal have been generous in extending their logistical support. Finally, I would like to thank all those institutions-such as the Chinese Academy 'of Sciences, Agro-economic Research Centre, the University of Himachal Pradesh, the Agricultural Projects Services' Centre, Nepal, the Aga Khan Rural Support Project Pakistan, and the Planning Commission and Ministry of Agriculture of the Royal Government of Bhutan-which have given this search for Strategies for Sustainable Agriculture their valuable support.

DR. E.F. TACKE Director, ICIMOD 


\section{PREFACE}

Economic development has been a long, slow process for much of the developing world. This is especially so for the peoples who inhabit the mountainous region of Asia. In the two decades after World War II development strategies emphasised the importance of growth in per capita income and food production, in the expectation that the benefits of such growth would be universal, "trickling down" to the poorest communities. Growth was achieved, but there was little evidence of trickle down. Rapidly increasing food production was brought about by the Green Revolution but the benefits were mostly confined to the flat, well irrigated lands of Asia. Few of the new miracle varieties of rice and wheat were suitable for mountain environments and the technologies that went with them were inappropriate, if not damaging. Development thinking in the late 1960s and 1970s shifted to an emphasis on growth with redistribution and on satisfying certain "basic needs" - nutrition, health, water supply, shelter, sanitation and education. The new strategies accepted that poverty could not be eliminated solely by economic growth and required a direct attack, mobilising government and aid spending rather than relying on market forces. This has undoubtedly brought considerable benefits. Mountain people are now better served than at any time in the past by schools and primary health care centers, potable water supplies and veterinary clinics as well as by improved roads and access to markets. Yet, at the same time, the resource base on which these people depend has deteriorated at an accelerating rate. The roads and markets have been a mixed blessing, encouraging unbridled exploitation. Forests have been felled, the vegetation cover removed and steep slopes have become severely eroded. Together with exploitation, the impact of population pressure and inappropriate technologies have severely degraded the mountain environment.

Such resource degradation is not unique to the mountains although is perhaps more dramatically obvious there. Elsewhere in the world has come a growing realisation of the perils of the damage we are causing to our natural resources and environment. In 1987 the issues were given worldwide attention by the publication of the World Commission on Environment and Development report "Our Common Future". In addition to illustrating the problems we face the Brundtland Report, as it is known, called for a new strategy of sustainable development as a basis for economic growth in the coming decades.

Following the publication of the report the concept of sustainable development has caught the imagination of policy makers, economic, social and environmental advisers and leaders of the non government community. Policy and programme proposals, project documents and plans are invariably replete with references to the need for sustainability. Yet few use the term precisely. It has come to mean all things to all men and women. 
In the Brundtland Report sustainable development is "development that meets the needs of the present without compromising the ability of future generations to meet their own needs." Such a definition resonates with our ideals and our humanity but is not readily translated into a plan of practical action.

Today we are in urgent need of more practical, down to earth interpretations of sustainability. We need to be in a position to ask and answer, with precision, such questions as "Is this cropping system sustainable?" "Is this forest sustainable under the present pattern of exploitation?" "Is this watershed sustainable under the present regime?" "Is the current lifestyle of these people sustainable?" And, if the answers are "no", how can the sustainability be improved? We also need to be aware that sustainability - the ability of the field or village or watershed to survive may involve costs. There may well be trade-offs in development between sustainability, economic growth and equity for instance. Designing a sustainable, but essentially static, resource management regime may be relatively easy. It will be considerably more difficult to design one that is sustainable yet also provides growing incomes that are equitably shared.

These are the formidable challenges of the 1990s and the 21 st century. They are faced by all peoples of the world, but perhaps most acutely by mountain people. The concept of sustainable development faces its severest test in mountain environments. At the same time, the acute and dramatic nature of resource degradation in the mountains brings the issues into sharp relief. Success may well carry lessons for other environments elsewhere in the world.

This book addresses many of the central issues of sustainable agricultural development in the mountains. It provides innovative concepts, detailed case studies and thoughtful analysis. Readers will find a wealth of information, ideas and examples of practical experiences culled from a wide range of countries and mountain environments.

\section{PROFESSOR GORDON R. CONWAY}

Representative, India, Sri Lanka, Nepal and Professor, Centre for Environmental Technology Imperial College of Science, Technology and Medicine, London 


\section{EDITORS' NOTE}

The work presented in this book covers various dimensions and issues relating to mountain agriculture in the overall context of development strategies, experiences, problems and prospects in the mountain areas with special focus on the Hindu Kush-Himalayan region. ICIMOD's work on the subject during the last three years supplemented by contributions from other institutions and experts in the International Symposium on Strategies for Sustainable Mountain Agriculture in September 1990, determined the overall scope of the book. Besides adding to the depth and variety of issues, this also increased the size of the book. For the reasons of comprehensive reporting on the subject and protecting linkages between different aspects covered by conceptual and empirical work extending to different geographical areas and relating to a range of themetic contexts, it was difficult to exclude some material to reduce the size of the book.

Concerned with the possible operational problems and convenience of readers, the whole book is divided into two volumes, published simultaneously. The thematic coverage of the two volumes is governed by closer linkages between the issues and evidence covered by different papers. Accordingly, Volume 1 focusses on agricultural development perspectives, approaches, and strategies in the HKH region. The long-term sustainability issues and use of agro-ecological zonation as a tool for development planning in mountain areas are other important aspects covered by Volume 1. Volume 1 consists of 15 chapters.

Volume 2 covers relatively more operational dimensions of the subject where microlevel or project-level realities, experiences and implications are reported and analysed. Chapters dealing with farmers' strategies and some innovative project initiatives are covered by Volume 2 . Volume 2 consists of 18 chapters.

N.S. JODHA, M. BANSKOTA and TEJ PARTAP (editors) 


\section{ACKNOWLEDGEMENTS}

Acuteness of environmental degradation and poverty in mountain regions of the developing countries is now well recognised. The problems are sharply manifested by the stagnation and decline of Agriculture the major activity of mountain people. Understanding of the factors and processes contributing to this decline and identification and adoption of possible solutions is a herculean task. This is more so due to specific conditions characterising mountains and general disregard of mountain regions in the past by researchers and policy makers alike.

To address the above problem ICIMOD attempted to mobilise available knowledge and evidence on different aspects of the problem through an International Symposium on Strategies for Sustainable Mountain Agriculture and subsequently present the relevant material through the two volumes before all those associated with development of mountain areas. We take this opportunity to thankfully acknowledge the help of all those who have contributed in this task.

Our thanks are due to the authors who not only managed to prepare and revise their contributions under tight time schedules but many of them presented their evidence and argument in the overall context of mountain-perspective sustainability framework suggested by us.

We would also like to thank Mrs. Greta Rana and Mrs. Archana Karki for their assistance in language editing. This made the job easier for the publishers. The secretarial assistance from Mrs. Sami Joshi and Reeta Rana deserves praise specially for the hardwork they did in typing the manuscript time and again for several months.

Finally we thank ICIMOD Director and all our professional staff colleagues. Their cooperation and involvement in programme activities from time to time saw successful completion of the project and production of this book.

N.S. JODHA, M. BANSKOTA and TEJ PARTAP (editors) 


\section{THE CONTRIBUTORS}

Bajracharya B.B.

Centre for Economic Development and

Administration (CEDA)

Tribhuvan University

P. O. Box 797, Kirtipur

Nepal

\section{Bajracharya D.}

Division Head

Mountain Population and Employment Division ICIMOD, G.P.O. Box 3226, Kathmandu, Nepal

\section{Banskota M.}

Chief Programme Coordinator and

Programme. Head,

Area Development Planning and

Implementation

ICIMOD, G.P.O. Box 3226, Kathmandu,

Nepal

\section{Bhati J.P.}

Department of Economics

Himachal Pradesh University

Shimla, India

\section{Burathoki K.}

Lumle Agriculture Centre (LAC)

P. O. Box 1

Pokhara, Kaski, Gandaki Zone

Nepal

\section{Camino A.}

Director

Fundacion Peruana

Para la Conservacion de la

Naturaleza (FPCN)

Chinchon 858/A

San Isidro, Aptdo.18-1393

Lima, Peru
Carson, B.

Project Leader

Master Plan for Horticulture, HMG,

East Consultants Co. Ottawa,

Canada

\section{Chand S.P.}

Agronomist

Pakhribas Agriculture Centre (PAC)

c/o BTCO, P. O. Box 106

Kathmandu, Nepal

Dafu Y.

Chengdu Institute of Mountain

Disaster and Environment

Chengdu, P.O. Box 417

Sichuan, China

\section{Denholm J.}

Mountain Farming Systems Division

International Centre for Integrated Mountain

Development (ICIMOD), G.P.O. Box 3226,

Kathmandu, Nepal

Fei $\mathbf{W}$.

Chengdu Institute of Mountain

Disaster and Environment

Chengdu, P. O. Box 417

Sichuan, China

Gupta A.K.

Centre for Management in Agriculture,

Indian Inst. of Management

Vastrapur, Ahmedabad

India

Hongbin G.

Leading Group Office for the Economic

Development of Poor Areas

Beijing

China 


\section{Husain $\mathrm{T}$.}

Managing Director

Development Research and Management

Services

P.O. Box 2389

Islamabad, Pakistan

\section{Jodha N.S.}

Division Head

Mountain Farming Systems Division

International Centre for Integrated Mountain

Development

(ICIMOD), G.P.O. Box 3226, Kathmandu, Nepal

\section{Joshi B.R.}

Lumle Agricultural Centre (LAC)

P. O. Box I

Pokhara, Kaski, Gandaki Zone,

Nepal

\section{Katwal B.}

Agriculture Projects and Services Centre

(APROSC)

G. P. O. Box 1440

Ramshah Path

Kathmandu, Nepal

\section{Karim Z.}

Mountain Environment and Natural Resources Information Services (MENRIS)

ICIMOD, G.P.O. Box 3226, Kathmandu, Nepal

Keatinge J.D.H.

International Centre for Agricultural Research in the Dry Areas (ICARDA)

P.O. Box 5466, Aleppo, Syria

\section{Khan R.}

Director

Arid Zone Research Institute

P.O. Box 362

Quetta, Pakistan

Kotta P.K.

Mountain Environment and Natural Resources Information Services (MENRIS)

ICIMOD, G.P.O. Box 3226, Kathmandu, Nepal

\section{Lundberg, P.A.}

Chief Technical Advisor to Planning

Commission

HMG Nepal on Regional Development
Planning

United Nations Development Programme

(UNDP)

Pulchowk

Kathmandu, Nepal

Mr. Mulk M. UI

Aga Khan Rural Support Programme

District Programme Office, (AKRSP)

NWFP, Pakistan

\section{Mya S.}

Mountain Environment and Natural Resources Information Services (MENRIS)

ICIMOD, G.P.O. Box 3226, Kathmandu, Nepal

\section{Mr. Nakarmi G.B.}

Geologist

Integrated Survey Section Topographic Survey Branch

P. O. Box 1611, Min Bhawan, Kathmandu, Nepal

Ning $\mathbf{W}$ :

Chengdu Institute of Biology

Academia Sinica

P.O. Box 416,610015

Chengdu, Sichuan, China

Partap T.

Mountain Farming Systems Division

ICIMOD, G.P.O. Box 3226, Kathmandu, Nepal

\section{Pound B.}

Director

Lumle Agricultural Centre

c/o BTCO, P. O. Box 106

Kathmandu, Nepal

Pradhan P.

Mountain Environment and Natural Resources

Information Services (MENRIS)

ICIMOD, G.P.O. Box 3226, Kathmandu, Nepal

Rathore M.S.

Senior Research Fellow

Institute of Development Studies

B-124, Mangal Marg

Bapunagar, Jaipur

India

Rhoades R.E.

Professor and Head 
Department of Anthropology

University of Georgia Athens

Georgia, 30602

USA

Sharma K.S.

Integrated Development Service

New Baneswor

Kathmandu, Nepal

Sharma L.R.

Agroeconomic Research Centre

Himachal Pradesh University

Shimla, India

Sharma P.

Mountain Population and Employment

Division

ICIMOD, G.P.O. Box 3226, Kathmandu, Nepal

Sharma S.

Mountain Infrastructure and Technology

Division

ICIMOD, G.P.O. Box 3226, Kathmandu, Nepal

Shrestha S.

Mountain Farming Systems Division

ICIMOD, G.P.O. Box 3226, Kathmandu, Nepal

Tapia M.E.

Proyecto de Investigacion

de Sistemas Agropecurios Andenos (PISA)

INIAA, Box 110697

Lima 11, Peru

Thapa B.

Pakhribas Agricultural Centre

Dhankuta District

Koshi Zone, Nepal

c/o BTCO, P.O. Box 106

Kathmandu, Nepal

Ura $\mathbf{K}$.

Planning Officer
Planning Commission

Royal Government of Bhutan

Thimpu, Bhutan

Velde E.J.V.

Professor

International Irrigation Management

Institute (IIMI)

Country Office, Islamabad, Pakistan

Verma L.R.

Mountain Farming Systems

ICIMOD, G.P.O. Box 3226, Kathmandu, Nepal

Xingqing $\mathbf{Y}$.

Leading Group Office for the Economic

Development of Poor Areas

Beijing

China

Yanhau Liu

Institute of Geography

Chinese Academy of Sciences (CAS)

Beijing, 100012

China

Yadav Y.

Agricultural Projects and Sęrvices Centre (APROSC)

Post Box 1440,

Kathmandu, Nepal

Zhaoguang L.

Director

Chengdu Institute of Biology

Academia Sinica

P. O. Box 416, 610015

Chengdu, Sichuan, China

Zimmerer $\mathbf{K}$.

Assistant Professor

Department of Geography

University of Wisconsin, Madison

WI 53706, USA 